\title{
Eucalyptus sp. at the Intersection of Environment and Culture in Kenya
}

\author{
Brandy Garrett Kluthe ${ }^{1 *}$ and Diana Chen ${ }^{2}$ \\ ${ }^{1}$ Biology Department, University of Arkansas, Fayetteville, AR, USA. ${ }^{2}$ Anthropology Department, University of Arkansas, \\ Fayetteville, AR, USA. \\ *brandygarrettkluthe@gmail.com
}

\begin{abstract}
Members of the genus Eucalyptus are popular on small farms throughout Kenya, and include species such as Eucalyptus saligna, Eucalpytus globulus, and Eucalyptus grandis. Although they are fast-growing and perform well on marginal land, these trees are associated with negative environmental effects in Africa and elsewhere they have been introduced. In-person surveys were conducted with small farmers in Kenya to determine patterns of Eucalyptus sp. stand use and cultural importance. It was found that despite acknowledged short and long term environmental consequences, Eucalyptus sp. remains popular for medium term economic investment. These findings are consistent with other reports of Eucalyptus sp. woodlots serving as funding sources for education, health emergencies, etc., in parts of the world where bank loans are unavailable. Further, it was found that some farmers are using modified silviculture practices to ameliorate the negative effects of Eucalyptus sp., and others are seeking indigenous alternatives.
\end{abstract}

Received May 27, 2016

OPENӘACCESS

Accepted November 10, 2016

DOI 10.14237/ebl.8.1.2017.706

Keywords Eucalyptus sp., Kenya, Farmers, Environment, Economics

Copyright (c) 2017 by the author(s); licensee Society of Ethnobiology. This is an open-access article distributed under the terms of the Creative Commons Attribution-NonCommercial 4.0 International Public License (https://creativecommons.org/licenses/by-nc/4.0), which permits non-commercial use, distribution, and reproduction in any medium, provided the original author and source are credited.

\section{Introduction}

The introduction of Eucalyptus sp. to East Africa was driven by the need for a fast-growing wood source to fuel that expansion of the railroad system (Bennett 2010). Native to Australia, the Eucalyptus genus was traditionally used by aboriginal tribes for medical purposes (Webb 1969). However, the rapid expansion of Eucalyptus sp. to other parts of the world during the nineteenth century did not necessarily mean the translation of all of their medicinal uses to new cultures. Although selected species are reportedly used in parts of Africa to treat some ailments (Kokwaro 1995; Njoroge and Bussmann 2006; Njoroge and Bussmann 2007), a recent survey of medicinal plants in Western Kenya near indigenous forest showed no indication that Eucalyptus sp. was utilized (Otieno and Analo 2012). Eucalyptus sp. came to Kenya with British colonists over a century ago, however it was only in the past couple of decades that it achieved ubiquity there (Peralta and Swinton 2009; Scherr 1995).

Prior to British colonization, native Kenyans included groups of farmers, herders, and those who represented a combination of the two (Ndege 2009).
The diverse cosmos of these groups, including the Kikuyu, Maasai, and Embu, reflected a deep ecology with various beliefs and taboos surrounding native trees (Tom 2010; Wane and Chandler 2002). European influence in Kenya not only altered the ecology as new species such as Eucalyptus sp. were introduced, but it also had a detrimental impact on the existing social order. European settlements created property boundaries and disrupted trade routes, pushing pastoral and agrarian society into less productive areas. Pastoral groups such as the Maasai, who depended upon free range grazing and trade with agrarian groups, could no longer move freely around the region (Castro 1991). Restricted movement and limited natural resources resulted in disputes among ethnic groups, both with each other and with the European settlers (Ndege 2009). The cessation of group mobility has also limited the ability of people to cope with climate change (Watson and Kochore 2012).

Europeans also profoundly changed Kenyan agriculture by shifting it from a subsistence focus to one of profits and exports (Doughty 1996). Whereas traditional societies typically focused on ecologic 
exchanges (Toledo 2002), large expanses of land planted in monoculture crops such as wheat (Buckley 1903) changed the social focus to economic exchanges. The introduction of coffee and tea altered Kenyan agriculture even more. The curing process of these crops secured the continued cultivation of Eucalyptus sp. While still widely used for construction, it quickly became the preferred fuelwood source on tea plantations (Ojany and Ojendo 1982; Taku 1999).

With a rising demand for fuelwood, and increased governmental promotion of Eucalyptus sp. as a fast growing wood source, small plot farmers planted the trees for potential economic benefits (Doughty 1996). This increase in cultivation also came with concerns from farmers who noticed that water sources were becoming compromised and crops growing near Eucalyptus sp. exhibited poor growth (Bennett 2010). Indeed, negative effects of Eucalyptus sp. may include increased acidity in both the soil and nearby water sources (Luzar 2007), toxicity to fish (Webb 1969), and the ability to outcompete native plants for water and nutrients - which then leads to increased erosion because of decreased undergrowth (Luzar 2007).

The entire African continent has been identified by Western scientists as a region extremely "vulnerable" to climate change (Watson and Kochore 2012). Bankoff (2001:24) describes the Western concept of vulnerability as it applies to Africa and other non-Western regions as the "historical and social," as well as the "geographic or climatic predisposition to hazard." To truly address environmental problems, it is important to understand the social factors leading to vulnerability, such as the decision making practices of small scale farmers who choose to plant non-native species.

The recognition of changes in the ecosystem, such as those wrought by Eucalyptus sp., falls into the realm of ethnoecology, the human appropriation of nature (Toledo 2002). The objective of this study was to assess the ethnoecological knowledge of small plot Eucalyptus sp. farmers. As discussed, the introduction of Eucalyptus sp. changed the culture of indigenous people living in pre-colonized East Africa. Today, the monetary benefits of growing Eucalyptus on small farmers' plots may come with environmental as well as social challenges. We use a cultural materialist (Harris 1966) framework to understand farmers' motives for growing Eucalyptus sp.

\section{Methods}

Study location

In order to assess farmers' ethnoecological knowledge of Eucalyptus sp. trees on their farms and elsewhere, a semi-structured survey (Figure 1) was administered to seventeen farming family heads from the Eastern, Central, Rift Valley, and Western Regions of Kenya in the Summer of 2015. Though surveys were mainly conducted randomly in central gathering places of villages, some farmers were also surveyed when ecological sampling took place in their personal woodlot. This data is part of a larger research project looking at the environmental effects of Eucalyptus sp. trees and their associated fungi.

\section{Data collection}

Fifteen male and two female farmers representing a wide age range were surveyed. Six of the farmers were "middle-aged" (35-50 years), four were "older" (5065 years), and two were "younger" (20-35 years). The remaining five farmers declined to indicate their age group. The initial question asked before conducting a survey was to determine if the person farmed and if they also grew Eucalyptus sp. trees. Only one survey was conducted per family unit. If the survey respondent was fluent in English then the survey was conducted in English. If the respondent was not fluent in English then an interpreter conducted the survey in the local language. Ten of the survey respondents used their native language to answer questions. Five spoke Swahili and five used a regional Luo language either throughout the entire survey or to answer a question more thoroughly.

The survey data was entered into Microsoft Excel and subsequently analyzed for developing an overall interpretation of farmer impressions of Eucalyptus sp. (Martin 1995) using QSR International's NVivo 11 Pro software following the methods for qualitative analysis of surveys outlined in Edhlund and McDougall (2016:253).

\section{Results}

The planting regimes for the trees varied but were all consistent with the literature on small scale Eucalyptus sp. farming (Oballa et al. 2010). The size of the plots ranged from an approximate 700 square meter plot to one hectare (average size of 0.30 hectares) with the exception of one that was approximately 20 hectares. The farmer of the largest plot was caretaker for a large plantation. All of the respondents planted their woodlots from seedlings with one third of them 
purchasing seedlings from government nurseries. The two farmers that grew their own seedlings collected seeds or stems from their own or neighbor's lots and germinated them in pots or temporary beds before out-planting the seedlings. All of the respondents reported planting Blue Gum, which is the common name for Eucalyptus globulus. However, most of the Eucalyptus sp. trees observed in the survey areas were Eucalyptus grandis or Eucalyptus saligna. It appears that the term "Blue Gum" is now commonly used to refer to most Eucalyptus species in Kenya and may not accurately reflect the actual tree species planted.

The farmers had some varied responses with respect to the seedling spacing in the woodlot. Most of the farmers planted their seedlings about one meter apart. Several of the farmers added that they would thin out the seedlings when they reached a certain size to an approximate three meter spacing. A few of the farmers planted their trees three or more meters apart. When asked how long they would let the trees grow, $65 \%$ responded that they would harvest in 10-15 years. The remaining farmers were split between approximately five years and more than 30 years, so 15 years was the overall average. However, two of the farmers talked about harvesting after a few years, then allowing the trees to coppice for a second harvest a decade or so later.

Traditional ethnoecological systems are typically multi-use (Toledo 2002). The farmers in this study were asked a series of questions about the use of their woodlots for Non-Timber Forest Products (NTFPs), which might include fuelwood, medicinal herbs, food, fodder, or honey. All of the respondents collected fallen Eucalyptus sp. branches for firewood. Three of those respondents also used larger limbs for light construction as well. None of the farmers gathered anything else that grew or lived in the Eucalyptus sp. woodlots. One farmer indicated that he would hunt an animal if it was found in the woodlot but did not specify the time when that occurred. A little more than half of the farmers had unsuccessfully tried to plant other crops or trees, including maize, cassava, beans, groundnuts, fruit trees or grasses for livestock in the Eucalyptus sp. Woodlots (Figure 2). As a main food staple in Kenya, maize was a crop that farmers would have liked to plant if it could grow well alongside Eucalyptus sp. (Ng'endo et al. 2015).

Although none of the farmers surveyed indicated that they gathered anything other than firewood from Eucalyptus sp. woodlots, more than half of them

Date
1. Farmer/villager age and gender
2. What is the approximate size of your woodlot?
3. How far apart to do you plant your trees? What is planted?
4. Do you use seeds or seedlings?
5. Where do you get your seeds or seedlings?
6. After how many years do you harvest your woodlot? How do you harvest
7. Do you collect the limbs and leaves that fall in the woodlot? Yes or No
8. If yes, what do you do with this?
9. Have you tried to plant other things in the woodlot? Yes or No
a. If yes, what have you tried to plant?
10. Do you collect anything from nearby forest? Yes or No
11. Do you collect anything that is only found with Eucalyptus?
12. Do you think Eucalyptus trees affect other plants that grow close them?
13. Do you think Eucalyptus used more water than other trees?
14. Do you see the same kinds of birds and animals in Eucalyptus forests and native forests?
15. What else can you tell me about Eucalyptus?

Figure 1 Farmer survey form used to interview farmers in several regions of Kenya to assess their impressions and uses of Eucalyptus trees. 


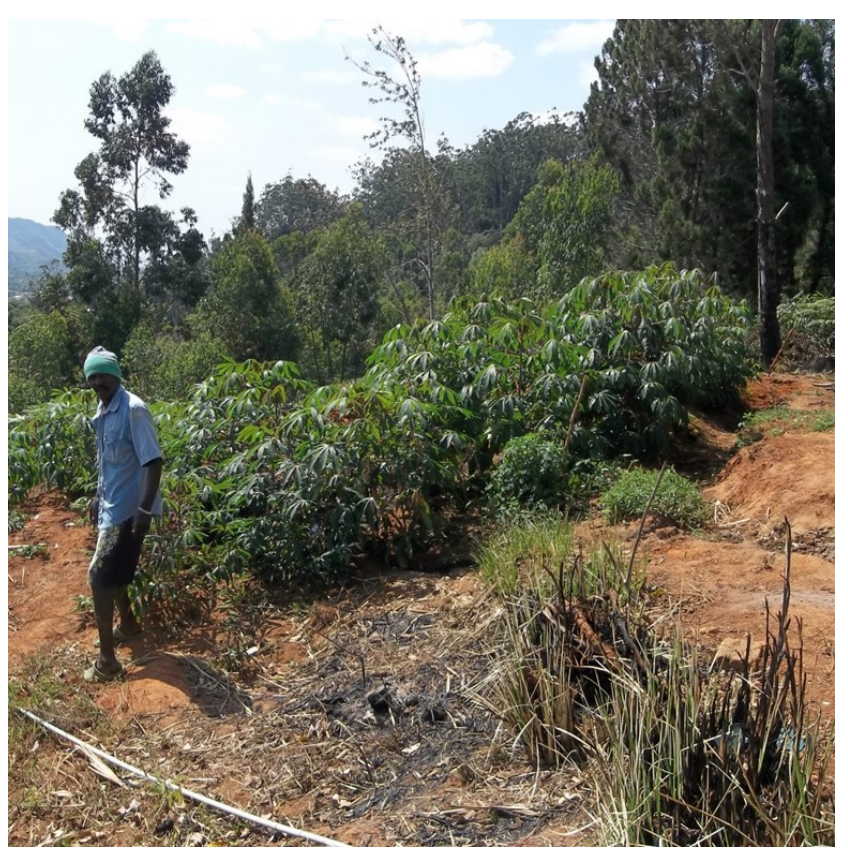

Figure 2 A cassava plot planted near Eucalyptus trees. The cassava closest to the Eucalyptus showed evidence of stunted growth (image by the author).

gathered items found in indigenous forests. These items included grasses for livestock, firewood, mushrooms, seeds, wild animals, and fruits. The latter was most frequently mentioned. The farmers were asked if the same kinds of birds and animals were found in both indigenous and Eucalyptus sp. forests and all responded no. A few gave examples of seeing monkeys or bats in the Eucalyptus sp. forests. Many of the farmers reported that the indigenous forest had many more animals and birds, with some saying that no animals or birds could be found in the Eucalyptus sp. forests.

The farmers were asked if the Eucalyptus sp. trees had an effect on other plants that grew close to them. All of the farmers said yes. They volunteered that the ground would get very dry and that other plants would not grow well. One farmer replied that he grew the Eucalyptus sp. only on hillsides where he could not grow crops. Similarly, another farmer grew Eucalyptus sp. in "dry mountain places." Another adaptation to Eucalyptus sp. farming included trenching around trees to prevent allelopathy. When asked about water usage, all of the farmers reported that they thought Eucalyptus sp. used more water than other trees. Some gave examples of planting trees in wet areas that are now dry. The names for Eucalyptus in local languages reflect this thirst. They are called drinking water in
Mukungugu (Kaburi and Medley 2011) and Embu (Wane and Chandler 2002).

Each farmer was asked if they had anything else they would like to share about Eucalyptus sp. Most of the comments elicited were positive, or implied that the positive aspects of Eucalyptus sp. farming outweighed the environmental challenges. Farmers appear to like Eucalyptus sp. trees because they grow well and fast. However, a couple of farmers talked about the leaf litter and how it doesn't break down. They said it just keeps building up and doesn't allow the rain the reach the ground. One quarter of the farmers surveyed stated that they wanted or planned to clear the Eucalyptus sp., burn the stumps, and replace it with either Grevillea robusta A.Cunn. ex. R.Br. or indigenous plants. This may be linked to recent government recommendations on the planting of Eucalyptus sp. but was not specifically addressed in any of the farmers' responses.

During one conversation with a farmer, he spoke about why the harvest time was from 10-15 years. He said that when a man married and started his own farm he would plant Eucalyptus sp. trees if he had the space. He would then leave the trees until it was time for his children to go to secondary school, which in many cases requires boarding fees. He would then harvest his trees and have enough money for his children to continue their education. In a sense, the trees were acting as a saving account that accumulated interest as the trees grew in size and value. Other studies across the developing world agree that this practice is very common not just for education but for medical bills, planting crops, or other emergencies when large sums of money would be needed at once (Hill 1961; Quinlan et al. 2015; Snyder and Cullen 2014).

\section{Discussion}

In several instances, the wives of respondents were present but the men gave the survey answers. This is consistent with Lado's (2004) surveys of Kenyan farmers in which $87 \%$ of households were headed by males. In 1989, Bentley observed of small scale farmers in Honduras that there are often gaps between what he called "Indigenous Technical Knowledge" (which is now more commonly called Traditional Ecological Knowledge, or TEK) and Western scientific knowledge. According to Bentley, the difference is often one of visibility or perception. For example, the farmers in his study had the most information about plants, a lesser amount of 
information about insects, and only a small amount on the subject of bacterial/fungal diseases of plants (Bentley 1989). The overall impression left by the data from this study however is that small scale farmers in Kenya are entirely aware that the Eucalyptus sp. woodlots reduce diversity, impede nearby plants, and use a lot of water. Therefore the environmental message has gotten across. However, there appears to be widespread ambivalence to this message, just as Kollmuss and Agyeman (2002) have identified a gap between the pro-environmental thoughts and behaviors of people in general. The continued planting of Eucalyptus sp. indicates that the monetary benefits outweigh the negatives. This idea aligns with Harris's famous 1966 work on adaptive ecological systems that may at first seem incomprehensible to outsiders. Small farmers in Kenya rely heavily on remittances sent from relatives off working in cities (Nyasimi et al. 2007), even though the loss of on farm labor negatively affects the homestead (Greiner and Sakdakpolrak 2012). Diversification of farms into part -woodlots is one path to success (Nyasimi et al. 2007). As long as Kenya remains a net importer of wood (Jerneck and Olsson 2013), small farmers will have an economic incentive to grow Eucalyptus sp. New hybrid varieties of Eucalyptus with faster growth rates have increased the eagerness of farmers to plant the trees. The increased growth rate allows for a much earlier harvest resulting in more generations of trees harvested in the same amount of time as one previous generation. Based on an average wood lot size of one hectare, the approximate net income from the sale of the harvested trees is over six thousand (US) dollars (Oballa 2010). Harvesting the trees in just five years instead of the longer harvest age of 8-10 years greatly increases the farms' income (Kirongo et al. 2014). That amount of money effectively doubles the annual income of the average Kenyan household (The World Bank 2016).

When farmers decide what to plant, their culture affects their choice (Quinlan et al. 2015). In some places in Kenya the productivity of the land is tied to adherence to proper behavior (Nyasimi et al. 2007). Cultural rules may prevent best farming and land stewardship practices as indicated in the research by Nyasimi et al. (2007) which state that women are not allowed to work on the farm unless certain conditions are met. This has led to severe land degradation in some areas. Planting Eucalyptus sp. relies on less input both of time and resources for a success woodlot. This may appeal to farmers as a way to overcome some cultural restrictions.

It is perfectly normal for Kenyans to plant Eucalyptus sp. The data generally show a lack of active decision making. Most Kenyan farmers plant the trees because their neighbors do (Benjamin and Blum 2015), because their government encourages it, and because it's a way to save up money for future expenses. "Land in Sub-Saharan Africa is not merely a commodity - it is the most important economic and social asset (Snyder and Cullen 2014:15)." Using their ecological knowledge and scientific findings (such as those from the larger project this paper represents), farmers can take steps to mitigate the environmental impacts of planting Eucalyptus sp. while still growing it successfully. Indeed, some farmers have indicated that they are using counter measures to combat the negative effects of Eucalyptus sp. trees and others indicated an interest in planting different trees and crops. For example, farmers are planting the Eucalyptus in dry areas where other crops won't grow. The reasons for doing so are to reduce pressure on water sources for sustainability, or to appease next door neighbors for social reasons.

The one farmer who tore up his Eucalyptus sp., burned the stumps, and planted banana instead reported that his farm is doing well. Agrobiodiversity factors into social prestige. Farmers with more trees and crops tend to be wealthier and older (but not necessarily have larger farms), and wild foods tend to have low status (Ng'endo et al. 2015). However, Ng'endo et al. (2015) and Connelly and Chaiken (2000) found that agrobiodiversity was no guarantee of food or financial security.

The introduction of Eucalyptus sp. in Kenya has profoundly impacted both the culture and agricultural environment, changing the way Kenyans live and interact with the land. Even with the knowledge that Eucalyptus presents some ecological concerns, farmers grow the trees for the monetary benefits. Ownership of Eucalyptus sp. woodlots increases the value of the farm and can provide some security against unknown financial hardships. Continued planting of this introduced tree will likely become part of the subsistence farming culture of Kenya.

\section{Acknowledgments}

Appreciation is extended to Phanuel O. Oballa, Jared Amwatta Mullah, Joram M. E. Mbinga and Willis A. Atie and several other individuals associated with the Kenya Forest Research Institute (KEFRI); George G. 
Ndiritu and the staff of the National Museums of Kenya; and Francis Onduso, research colleague and guide in Kenya. Special thanks are extended to Dr. Steve L Stephenson and Dr. Justin Nolan with the University of Arkansas for their guidance in the collection and compilation of this research.

\section{Declarations}

Permissions: The present research was deemed exempt from IRB review on February 11, 2016.

Sources of Funding: Partial funding for this project was through a graduate travel grant from the University of Arkansas.

Conflicts of Interest: None declared.

\section{References Cited}

Bankoff, G. 2001. Rendering the World Unsafe: 'Vulnerability' as Western Discourse. Disasters 25:19-35. DOI:10.1111/1467-7717.00159.

Benjamin, E. O., and M. Blum. 2015. Participation of Smallholders in Agroforestry Agri-Environmental Scheme: A Lesson from the Rural Mount Kenyan Region. The Journal of Developing Areas 49:127-143. DOI:10.1353/jda/2015.0125.

Bennett, B. M. 2010. The El Dorado of forestry: The Eucalyptus in India, South Africa, and Thailand, 1850-2000. International Review of Social History 55: 27-50. DOI:10.1017.S0020859010000489.

Bentley, J. W. 1989. What Farmers Don't Know Can't Help Them: The Strengths and Weaknesses of Indigenous Technical Knowledge in Honduras. Agriculture and Human Values 6:25-31. DOI:10.1007/BF02217666.

Buckley, R. B. 1903. Colonization and Irrigation in the East Africa Protectorate. The Geographical Journal 21:349-371. DOI:10.2307/1775678.

Castro, A. P. 1991. Indigenous Kikuyu Agroforestry: A Case Study of Kirinyaga, Kenya. Human Ecology 19:1-18. DOI:10.1007/BF00888974.

Conelly, W. T., and M. S. Chaiken. 2000. Intensive Farming, Agro-Diversity, and Food Security Under Conditions of Extreme Population Pressure in Western Kenya. Human Ecology 28:19-51. DOI:10.1023/A:1007075621007.

Doughty, R. 1996. Not a Koala in Sight: Promotion and Spread of Eucalyptus. Cultural Geographies 3 200-214. DOI:10.1177/147447409600300205.

Edhlund, B. M., and A. G. McDougall. 2016. NVivo
11 Essentials: Your Guide to the World's Most Powerful Data Analysis Software. Form and Kunskap AB, Stallarholmen, Sweden.

Greiner, C., and P. Sakdapolrak. 2012. Rural-Urban Migration, Agrarian Change, and the Environment in Kenya: A Critical Review of the Literature. Population and Environment 34:524-553. DOI:10.1007/s11111-012-0178-0.

Harris, M. 1966. The Cultural Ecology of India's Sacred Cattle. Current Anthropology 7:51-66. Available at: http://www.jstor.org/ stable/2743946. Accessed on February 17, 2017.

Hill, P. 1961. The Migrant Cocoa Farmers of Southern Ghana. Africa: Journal of the International African Institute 31:209-230. DOI:10.2307/1157262.

Jerneck, A., and L. Olsson. 2013. More Than Trees! Understanding the Agroforestry Adoption Gap in Subsistence Agriculture: Insights from Narrative Walks in Kenya. Journal of Rural Studies 32:114-125. DOI:10.1016/j.jrurstud.2013.04.004.

Kaburi, S. M., and K. E. Medley. 2011. Community Perspectives on Fuelwood Resources in East Africa. Mountain Research and Development 31:315324. DOI:10.1659/MRD-JOURNAL-D-1000121.1 .

Kirongo, B. B., K. Senelwa, G. K. Kimani, I. Moses, O. Augustino, and L. Etiégni. 2014. The Commercial Profitability of Growing Hybrid Eucalyptus Clones in The Cost Province, Kenya. Jurnal Manajemen Hutan Tropika 20:35-42. DOI:10.7226/jtfm.20.1.35.

Kokwaro, J. O. 1995. Ethnobotany in Africa. In Ethnobotany: Evolution of a Discipline, edited by R. Evans Schultes and S. von Reis, pp. 216-225. Timber Press, Portland, OR.

Kollmuss, A., and J. Agyeman. 2002. Mind the Gap: Why do People Act Environmentally and What are the Barriers to Pro-Environmental Behavior? Environmental Education Research 8:239-260. DOI:10.1080/13504620220145401.

Lado, C. 2004. Sustainable Environmental Resource Utilisation: A Case Study of Farmers' Ethnobotanical Knowledge and Rural Change in Bungoma District, Kenya. Applied Geography 24:281 -302. DOI:10.1016/j.apgeog.2004.03.002.

Luzar, J. 2007. The Political Ecology of a "Forest Transition": Eucalyptus Forestry in the Southern 
Peruvian Andes. Ethnobotany Research and Applications 5:85-93. Available at: http:// hdl.handle.net/10125/222. Accessed on February 17, 2017.

Martin, G. J. 1995. Ethnobotany. University Press, Cambridge, United Kingdom.

Ndege, P. O. 2009. Colonialism and Its Legacies in Kenya. Lecture presented at the Fulbright-Hays Seminars Abroad Program, Moi Univeristy, Kenya. Available at: http:// africanphilanthropy.issuelab.org/ resources/19699/19699.pdf. Accessed on July 9, 2015.

Ng'endo, M., G. B. Keding, S. Bhagwat, and K. Kehlenbeck. 2015. Variability of On-Farm Food Plant Diversity and Its Contribution to Food Security: A Case Study of Smallholder Farming Households in Western Kenya. Agroecology and Sustainable Food Systems 39:1071-1103. DOI:10.1080/21683565.2015.1073206.

Njoroge, G. N., and R. Bussmann. 2006. Traditional Management of Ear, Nose and Throat (ENT) Disease in Central Kenya. Journal of Ethnobiology and Ethnomedicine 2:54. DOI:10.1186/1746-4269-2-54.

Njoroge, G. N., and R. Bussmann. 2007. Ethnotherapeautic Management of Skin Diseases Among the Kikuyu of Central Kenya. Journal of Ethnopharmacology 111:303-307. DOI:10.1016/ j.jep.2006.11.025.

Nyasimi, M. K., M. L. Butler, C. L. Burras, H. Ilahiane, and R. C. Schultz. 2007. Differentiating Livelihood Strategies among the Luo and Kipsigis People in Western Kenya. Journal of Ecological Anthropology 11:43-57.

Oballa, P. O., P. K. A. Konuche, M. N. Muchiri, and B. N. Kigomo. 2010. Facts on Growing and Use of Eucalyptus in Kenya. Kenya Forest Research Institute, Nairobi, Kenya.

Ojany, F. F., and R. B. Ogendo. 1982. Kenya: A Study in Physical and Human Geography. Longman, Kenya.

Otieno, N. E., and C. Analo. 2012. Local Indigenous Knowledge about Some Medicinal Plants in and Around Kakamega Forest in Western Kenya. F1000Research 1:40. DOI:10.12688/ f1000research.1-40.v2

Peralta, M. A., and S. M. Swinton. 2009. Food vs. Wood: Dynamic Choices for Kenyan Smallholders. Paper presentation to the
Agricultural \& Applied Economics Association's 2009 AAEA \& ACCI Joint Annual Meeting, Milwaukee, WI. Available at http:// ageconsearch.umn.edu/bitstream/49401/2/ PeraltaSwintonAAEA09-1\%20.pdf. Accessed on March 12, 2015.

Quinlan, R. J., M. B., Quinlan, S. Dira, M. Caudell, A. Sooge, and A. A. Assoma. 2015. Vulnerability and Resilience of Sidama Enset and Maize Farms in Southwestern Ethiopia. Journal of Ethnobiology 35:314-336. DOI:10.2993/etbi-35-02-314-336.1.

Scherr, S. J. 1995. Economic Factors in Farmer Adoption of Agroforestry: Patterns Observed in Western Kenya. World Development 23:787-804. DOI:10.1016/0305-750X(95)00005-W.

Snyder, K.A., and B. Cullen. 2014. Implications of Sustainable Agricultural Intensification for Family Farming in Africa: Anthropological Perspectives. Anthropological Notebooks 20:9-29. Available at: http://hdl.handle.net/10568/53063. Accessed on February 17, 2017.

Taku, T. A. 1999. Framework for Industrialization in Africa. Praeger Publishers, Westport, CT.

The World Bank. 2016. Available at: http:// data.worldbank.org/country/kenya. Accessed on February 17, 2016.

Toledo, V. M. 2002. Ethnoecology: A Conceptual Framework for the Study of Indigenous Knowledge of Nature. In Ethnobiology and Biocultural Diversity, edited by J. R. Stepp, F. S. Wyndham, and R. K. Zarger, pp. 511-522. The International Society of Ethnobiology, Athens, GA.

Tom, E. G. 2010. Socio-economic and Cultural Aspects for Community Participation in Afforestation and Agroforestry Programmes: A Case Study of Teso District, Kenya. Available at: www.forestrynepal.org. Accessed on February 17, 2016.

Wane, N., and D. J. Chandler. 2002. African Women, Cultural Knowledge, and Environmental Education with a Focus on Kenya's Indigenous Women. Canadian Journal of Environmental Education 7:86-98. Available at: https://cjee.lakeheadu.ca/ article/view/275. Accessed on February 17, 2016.

Watson, E. E., and H. H. Kochore. 2012. Religion and Climate Change in Northern Kenya: New Moral Frameworks for New Environmental 
Challenges? Journal for the Study of Religion, Nature and Culture 6:319-343. DOI:10.1558/ jsrnc.v6i3.319.

Webb, L. J. 1969. The Use of Plant Medicines and Poisons by Australian Aborigines. Mankind 7:137146. DOI:10.1111/j.1835-9310.1969.tb00398.x. 